\title{
Assessment of primary health care: health professionals' perspective
}

\author{
AVALIAÇÃO DAATENÇÃO PRIMÁRIA À SAÚDE: VISÃO DOS PROFISSIONAIS DE SAÚDE \\ EVALUACIÓN DE LAATENCIÓN PRIMÁRIA EM LA SALUD: VISION DE LOS \\ PROFISSIONALES DE LA SALUD
}

\section{Simone Albino da Silva ${ }^{1}$, Denismar Alves Nogueira ${ }^{2}$, Camila Maria da Silva Paraizo³, Lislaine Aparecida Fracolli ${ }^{4}$}

\begin{abstract}
Objective: To assess primary health care attributes of access to a first contact, comprehensiveness, coordination, continuity, family guidance and community orientation. Method: An evaluative, quantitative and cross-sectional study with 35 professional teams in the Family Health Program of the Alfenas region, Minas Gerais, Brazil. Data collection was done with the Primary Care Assessment Tool - Brazil, professional version. Results: Results revealed a low percentage of medical experts among the participants who evaluated the attributes with high scores, with the exception of access to a first contact. Data analysis revealed needs for improvement: hours of service; forms of communication between clients and healthcare services and between clients and professionals; the mechanism of counter-referral. Conclusion: It was concluded that there is a mismatch between the provision of services and the needs of the population, which compromises the quality of primary health care.
\end{abstract}

\section{DESCRIPTORS}

Primary health care Health services evaluation

Family Health Strategy

Health personnel

\section{RESUMO}

Objetivo: Avaliar a Atenção Primária à Saúde por meio dos atributos: Acesso de Primeiro Contato, Integralidade, Coordenação, Longitudinalidade, Orientação Familiar, Orientação Comunitária. Método: Estudo avaliativo, quantitativo e transversal, realizado com 35 profissionais de equipes da Estratégia de Saúde da Família da microrregião de Alfenas, Minas Gerais, Brasil. Para a coleta de dados, foi utilizado o Primary Care Assessment Tool - Brasil, versão profissionais. Resultados: Os dados revelaram baixo percentual de profissionais médicos especialistas em Atenção Primária à Saúde. Os participantes avaliaram os atributos com altos escores, com exceção do Acesso de Primeiro Contato. A análise dos dados revelou necessidades de aperfeiçoamento: o horário de funcionamento dos serviços; as formas de comunicação entre usuário e serviço, e entre usuário e profissionais; o mecanismo de contrarreferência. Conclusão: Existe um descompasso entre a oferta de serviços e as necessidades da população que compromete a qualidade da Atenção Primária a Saúde.

\section{DESCRITORES \\ Atenção Primária à Saúde \\ Avaliação de Serviços de Saúde \\ Estratégia Saúde da Família \\ Pessoal de saúde}

\section{RESUMEN}

Objetivo: Evaluar la atención primaria de salud a través de las cualidades: Acesso de Primero Contacto, Intregidad, Coordinación, Longitudinalidad, Orientación Familiar, Orientación Comunitaria. Método: Se trata de una evaluación cuantitativa y estudio transverso con 35 equipos de profesionales de la Estrategia de Salud de la Familia, de región de Alfenas, Minas Gerais, Brasil. Para recopilar los datos, se utilizó el Instrumento de Evaluación de la Atención Primaria - Brasil, la versión Professional. Resultados: Los datos revelaron un bajo porcentaje de especialistas médicos en Atencion Primaria de Salud. Los participantes evaluó las calidades con puntajes altos, con la excepción de Acceso Primero Contacto. El análisis de datos reveló una mejora necesidades: horarios de apertura de los servicios; las formas de comunicación entre el usuario y el servicio y entre el usuario y el profesional, la remissión y consulta. Conclusión: Existe un desajuste entre la oferta de servicios y las necesidades de la población, lo que compromete la calidad de la Atención Primaria de Salud.

\section{DESCRIPTORES \\ Atención Primaria de Salud \\ Evaluación de Servicios de Salud \\ Estrategia de Salud Familiar \\ Personal de salud}

\footnotetext{
${ }^{1}$ Professor at the Nursing School of the Federal University of Alfenas, Alfenas - Minas Gerais, Brazil. ${ }^{2}$ Ph.D. Professor at the Nursing School of the Federal University of Alfenas, Alfenas - Minas Gerais, Brazil. ${ }^{3}$ Undergraduate student at the Nursing School of the Federal University of Alfenas, Alfenas - Minas Gerais, Brazil. ${ }^{4}$ Associate Professor, Department of Collective Health Nursing, School of Nursing, University of São Paulo, São Paulo - São Paulo, Brazil.

$\begin{aligned} & \begin{array}{r}\text { Rev Esc Enferm USP } \\ \text { 2014; 48(Esp):122-8 } \\ \text { www.ee.usp.br/reeusp/ }\end{array} \text { Received: 03/21/2014 } \\ & \text { Approved: } 07 / 06 / 2014\end{aligned}$
}




\section{INTRODUCTION}

In Brazil, the organization of primary care (PC) services was stimulated, beginning in the 1980s, by the movement for sanitary reform, under proposals for winning the right to health care, in an attempt to elevate social justice and citizenship. In the 90s, with the activation of the Unified Health System (SUS, as per its acronym in Portuguese), primary care was managed by the cities and developed by means of public policies and operational norms that ensured legal, administrative and financial support for the creation of the Family Health Strategy (FHS). The main objective of the FHS is to institute care practice, centered on the family, which must be understood from its physical and social environment. Having a qualitative and technological conception as a base, influenced by authors such as Starfield ${ }^{(3)}$, the FHS was consolidated as the great proposal for reorganizing PC in Brazil. It was incorporated on the National Policies of Primary Care editions.

Starfield pointed out the proper qualities PC, its essential attributes and derivatives. Essential attributes are: a) first contact access: healthcare services as a source of care for each new problem or new episode of one health problem, except for emergencies; b) longitudinal reach: the existence of continued sources of care and the expression of reliable mutual interpersonal relationships between the population and the service; c) comprehensiveness: comprehensive care, for both bio-psychosocial aspects and the health-illness process, adjusted to the context of PC; and d) coordination: availability of a network of information services regarding problems and previous services, and the acknowledgement of that information for the present service. Derived attributes are: a) familiar orientation: considering the familiar context and its care potential and threats to health in the evaluation of individual needs; b) communitarian orientation: acknowledging the health needs of the community by means of epidemiological data and its relationship with the community, the incentive to social control, as well as planning and joint evaluations of the services; and c) cultural competence and adjustment of the providers (health care teams and professionals) to the cultural characteristics special to the population to facilitate the relationships and communications with it. From these definitions, a form of evaluation of PC was established, verifying the presence and the reach of its attributes.

The rigorous identification of these attributes defines a service strongly based on primary health care. When composing the evaluation rates of PC, Starfield ${ }^{(3)}$ developed an appropriate instrument for this measurement, supported by the estimated evaluation in health of Donabedian. This instrument, called the Primary Care Assessment Tool (PCATool), was developed in U.S., and validated and translated to be applied in different countries, including Brazil. It comprises a complete process of utilization, capable of catching the perceptions of different social actors who interact in PC. The
PCATool has three versions: for adult clients, for children's responsible party (from 0 to 2 years) and for professionals.

The objective of this study was to evaluate, from the perspective of health professionals, whether the attributes of first contact access, comprehensiveness, coordination of healthcare services, longitudinal reach, familiar orientation, and communitarian orientation are practices incorporated in FHS teams.

\section{METHOD}

A quantitative approach evaluation study, with transversal delineation, that used the data base of the research Evaluation of the Attributes of Primary Care in the Health in Family Health Strategy in Cities of the South of Minas Gerais, approved by the Ethics Committee of the School of Nursing of the University of São Paulo (EEUSP), statement 30699 of 06/01/2012 and financed by National Council for Scientific and Technological Development (CNPq), process number 473768/2011-9.

Data collection was carried out in small-sized cities of the micro region of Alfenas, Minas Gerais, Brazil, in the months of June and July 2012. This micro region was chosen due to its broad coverage by the FHS and because it received from the state government of Minas Gerais many affirmative actions guided to professional qualification towards FHS work throughout the last decade. The inclusion criteria in this study were: being a doctor or nurse; at least one year of experience in the FHS team of an urban zone; implemented in cities with population coverage above $50 \%$ by the FHS; uninterruptedly functioning for at least five years; and who agreed to participate in the research by signing the Free and Informed Consent Form, in compliance with the current law.

Data were collected through interviews, carried out in the health units, with an average duration of 40 minutes. The data collection instrument was the Primary Care Assessment Tool -- PCATool Brazil, the professional version. It was composed of 77 items, divided into eight components regarding the attributes of PC: First Contact Access - Accessibility (A); Longitudinal Reach (B); Coordination - Integration of Care (C); Coordination - Information System (D); Comprehensiveness - Available Services (E); Comprehensiveness - Provided Services (F); Family Orientation (G); and Communitarian Orientation $(\mathrm{H})$. The possible answers for each one of the items were: certainly yes (value $=4$ ); probably yes (value $=3$ ); probably not (value $=2$ ); certainly not (value $=1$ ) and I do not know/I do not remember (value=9). Scores for each of the attributes or its components were calculated using the simple arithmetic mean of the values of answers from the items that compose each attribute or its component.

The answers on the instrument were organized in a data base created with Microsoft Excel and analyzed using Statistical Package for Social Sciences -- SPSS software, 
version 14.0, using a trust interval of $95 \%$ and descriptive statistics. Items from each attribute of PC, considered in the PCATool instrument, had an internal consistency and reliability evaluated by Cronbach's alpha.

\section{RESULTS}

The participants in this research were 34 health professionals, from 11 of the 17 cities of the micro region of Alfenas. Data collected in this study showed that, among these participants, $44.12 \%$ were doctors and $55.88 \%$ were nurses, with ages between 20 and 39 years (64.7\%); time since graduation more than five years (76.5\%); time of work in health services of one to five years (55.9\%); this being the only job for the majority (55.9\%); performing a weekly work load of 40 hours $(61.8 \%)$. The majority of the nurses $(89.48 \%)$ and a small number of the doctors (13.33\%) had some specialization in the FHS area (public health; primary care; family health; Family Health Program and family medicine).

Rates of PC attributes surveyed by employment of the PCATool comprised two categories defined by the boundary value 6.66. The results above this value were considered high scores and below, low scores, indicating a distance from the estimated quality of services. Table 1 shows the average values of scores attributed by the professional participants.

The majority of the attributes received a positive evaluation from health professionals. Analyzing particularly the items that composed the attributes First Contact Access -- Accessibility, Coordination - Integration of Care, and Comprehensiveness -- Available Services were chosen, since these received low scored evaluations or were close to the value of classification. Thus, the dimensions composing these attributes that were weak or strong could be evaluated, allowing better understanding of the results confirmed to the attribute itself (Table 2 ).

Table 2 demonstrates the low score of the attribute first contact access - accessibility resulted from the high percentages of negative evaluations for schedule provision of services to the public (A1, A2) and of communication means with the service and with some form of service care when the unit is not open (A4, A5, A6 and A7).
Table 1 - Average values and standard deviation of PC attributes confirmed by health professionals in the micro region of Alfenas - Alfenas, MG, 2012

\begin{tabular}{lcccc}
\hline Attributes & Minimum & Maximum & Mean & SD \\
\hline First Contact Access - & 2.22 & 7.04 & 4.13 & 1.25 \\
Accessibility & 5.13 & 9.74 & 7.86 & 1.17 \\
$\begin{array}{l}\text { Longitudinal reach } \\
\text { Coordination - Integration of }\end{array}$ & 4.44 & 10.00 & 6.91 & 1.49 \\
$\begin{array}{l}\text { Care } \\
\text { Coordination - Information }\end{array}$ & 4.44 & 10.00 & 8.95 & 1.37 \\
$\begin{array}{l}\text { System } \\
\text { Comprehensiveness - Available }\end{array}$ & 4.29 & 9.39 & 6.80 & 1.22 \\
$\begin{array}{l}\text { Services } \\
\text { Comprehensiveness - Provided }\end{array}$ & 4.89 & 10.00 & 8.01 & 1.24 \\
$\begin{array}{l}\text { Services } \\
\text { Familiar orientation }\end{array}$ & 4.44 & 10.00 & 8.82 & 1.39 \\
$\begin{array}{l}\text { Communitarian Orientation } \\
\text { Essential Score }\end{array}$ & 3.89 & 10.00 & 7.68 & 1.44 \\
General Score & 5.84 & 8.40 & 7.12 & 0.77 \\
\hline & 5.95 & 8.73 & 7.40 & 0.77 \\
\hline
\end{tabular}

In the version of the PCATool used for this study, the attribute Coordination was divided into Coordination - Integration of Care and Coordination - Information System, with the purpose of getting a better understanding of the results. Table 3 shows that the evaluations that contributed most for the mean score concerned the process of counter-referral to PC (C5), the poor knowledge about appointments in other care levels by PC professionals (C1), and the process of bad communication between professionals and clients before and after the referral to other services by the FHS.

The attribute Comprehensiveness also was divided into two components for better understanding of the results. The component Comprehensiveness - Available Services, despite being classified as scoring high, had its average next to the boundary-value of classification. The analysis of items in Table 4 demonstrates that these results were influenced by the high percentages of negative evaluations of the items regarding procedures classified as surgical and invasive (E9, E14, E18); orthopedic procedures (E13); immunizations (E2), identification of visual problems (E12), counseling/treatment for the use of licit and illicit drugs (E7); and counseling/treatment for ceasing to smoke (E16).

Table 2 - Percentile of answers to the attribute First Contact Access - - Accessibility, micro region of Alfenas - Alfenas, MG, 2012

\begin{tabular}{|c|c|c|c|c|c|c|c|c|c|}
\hline \multirow{2}{*}{ Evaluation } & A1 & A2 & $\mathbf{A 3}$ & A4 & A5 & A6 & A7 & A8 & A9 \\
\hline & $\%$ & $\%$ & $\%$ & $\%$ & $\%$ & $\%$ & $\%$ & $\%$ & $\%$ \\
\hline Certainly yes & 2.9 & 2.9 & 61.8 & 64.7 & 29.4 & 8.8 & 5.9 & 67.6 & 5.9 \\
\hline Probably yes & 0 & 11.8 & 38.2 & 26.5 & 2.9 & 2.9 & 0 & 29.4 & 20.6 \\
\hline Probably not / I do not know / I do not remember & 8.8 & 2.9 & 0 & 2.9 & 8.8 & 17.6 & 11.8 & 0 & 47.1 \\
\hline Certainty not & 88.2 & 82.4 & 0 & 5.9 & 58.8 & 70.6 & 82.4 & 2.9 & 26.5 \\
\hline Total & 100 & 100 & 100 & 100 & 100 & 100 & 100 & 100 & 100 \\
\hline
\end{tabular}

Notes: A1 - Is the health service open Saturday or Sunday? A2 - Is the health service open, for at least some days of the week until 8PM? A3 - When the health service is open and some patient becomes ill, does someone from the service see him/her on the same day? A4 - When the health service is open, can patients access fast counseling by the telephone whenever they judge necessary? A5 - When the health service is closed, is there a telephone number the patients can call when they become ill? A6 - When the health service is closed on Saturdays and Sundays and some patient becomes ill, does someone from the service see him/her on the same day? A7 - When the health service is closed at night and some patient becomes ill, does someone from the service see him/her at that same night? A8 - Is it easy for a patient to schedule a consultation for a health check (routine consultation, check-up) in the health service? A9 - In average, do patients have to wait 30 minutes or more to receive care service from the doctor or the nurse (not counting the triage and the reception)? $($ Cronbach's Alpha -0.501 , $\mathrm{N}=34$ ) 
Table 3 - Percentile of answers to the attribute coordination - integration of care, micro region of Alfenas- Alfenas, MG, 2012

\begin{tabular}{|c|c|c|c|c|c|c|}
\hline \multirow{2}{*}{ Evaluation } & C1 & $\mathrm{C2}$ & $\mathbf{C 3}$ & $\mathrm{C4}$ & $\mathbf{C 5}$ & C6 \\
\hline & $\%$ & $\%$ & $\%$ & $\%$ & $\%$ & $\%$ \\
\hline Certainly yes & 20.6 & 50 & 79.4 & 79.4 & 8.8 & 38.2 \\
\hline Probably yes & 41.2 & 29.4 & 20.6 & 11.8 & 8.8 & 41.2 \\
\hline Probably, not / I do not know / I do not remember & 29.4 & 20.6 & 0 & 2.9 & 41.2 & 14.7 \\
\hline Certainty not & 8.8 & 0 & 0 & 5.9 & 41.2 & 5.9 \\
\hline Total & 100 & 100 & 100 & 100 & 100 & 100 \\
\hline
\end{tabular}

Notes: C1 - Do you have knowledge of all the consultations that your patients have with specialists or specialized services? C2 - When your patients need referral, do you discuss with them the different services where they could have the service? C3 - Does someone from your health service unit help the patient to schedule a referral appointment? C4 - When your patients need referral, do you provide them with written information to take to the specialist or specialized service? C5 - Do you receive from the specialist or the specialized service any useful information on the patient? C6 - After the consultation with the specialist or the specialized service, do you speak with your patient about the results of this consultation? $($ Cronbach's alpha - $0.546, \mathrm{~N}=34)$

Table 4 - Percentile of answers to the attribute Comprehensiveness - Available Services, micro region of Alfenas- Alfenas, MG, 2012

\begin{tabular}{|c|c|c|c|c|c|c|c|c|c|c|c|}
\hline \multirow{2}{*}{ Evaluation } & E1 & E2 & E3 & E4 & E5 & E6 & E7 & E8 & E9 & E10 & E11 \\
\hline & $\%$ & $\%$ & $\%$ & $\%$ & $\%$ & $\%$ & $\%$ & $\%$ & $\%$ & $\%$ & $\%$ \\
\hline Certainly yes & 67.6 & 44.1 & 58.8 & 73.5 & 73.5 & 76.5 & 29.4 & 47.1 & 0 & 91.2 & 58.8 \\
\hline Probably yes & 5.9 & 11.8 & 26.5 & 5.9 & 2.9 & 17.6 & 44.1 & 41.2 & 5.9 & 5.9 & 14.7 \\
\hline $\begin{array}{l}\text { Probably not / I do not know / } \\
\text { I do not remember }\end{array}$ & 5.9 & 5.9 & 5.9 & 2.9 & 2.9 & 0 & 11.8 & 2.9 & 2.9 & 0 & 8.8 \\
\hline Certainty not & 17.6 & 35.3 & 2.9 & 14.7 & 17.6 & 2.9 & 11.8 & 5.9 & 88.2 & 0 & 14.7 \\
\hline Total & 97.1 & 97.1 & 94.1 & 97.1 & 97.1 & 97.1 & 97.1 & 97.1 & 97.1 & 97.1 & 97.1 \\
\hline \multirow{2}{*}{ Evaluation } & E12 & E13 & E14 & E15 & E16 & E17 & E18 & E19 & E20 & E21 & E22 \\
\hline & $\%$ & $\%$ & $\%$ & $\%$ & $\%$ & $\%$ & $\%$ & $\%$ & $\%$ & $\%$ & $\%$ \\
\hline Certainly yes & 44.1 & 17.6 & 2.9 & 91.2 & 61.8 & 79.4 & 0 & 67.6 & 67.6 & 94.1 & 64.7 \\
\hline Probably yes & 20.6 & 5.9 & 5.9 & 0 & 11.8 & 8.8 & 8.8 & 20.6 & 23.5 & 2.9 & 14.7 \\
\hline $\begin{array}{l}\text { Probably not / I do not know / } \\
\text { I do not remember }\end{array}$ & 8.8 & 8.8 & 2.9 & 2.9 & 11.8 & 0 & 2.9 & 2.9 & 5.9 & 0 & 5.9 \\
\hline Certainty not & 23,5 & 64.7 & 85.3 & 2.9 & 11.8 & 8.8 & 85.3 & 5.9 & 0 & 0 & 11.8 \\
\hline Total & 97.1 & 97.1 & 97.1 & 97.1 & 97.1 & 97.1 & 97.1 & 97.1 & 97.1 & 97.1 & 97.1 \\
\hline
\end{tabular}

Notes: If a patient needs any of the following services, could he/she get them in your health service unit? E1 - Nutritional counseling. E2 - Immunizations. E3 - Verify if the families can participate in some social assistance programs or benefits. E4 - Evaluation of buccal health. E5 - Dental treatment. E6 - Family planning or contraceptive methods. E7 - Counseling or treatment for the harmful use of drugs (licit or illicit). E8 - Counseling for mental health problems. E9 - Suture of a wound that needs stitches. E10 - Counseling on and request of HIV test. E11 - Identification (some type of evaluation) of auditory problems (listening). E12 - Identification (some type of evaluation) of visual problems (seeing). E13 - Splint placement (e.g.: twisted ankle). E14 - Wart removal. E15 Preventive examination for cervical cancer (Papanicolaou test). E16 - Counseling on how to quit smoking. E17 - Prenatal care. E18 - Ingrown nail removal. E19 - Guidance about health care in cases when the patient is incapacitated and cannot make decisions (e.g.: coma). E20 - Counseling about changes regarding aging (e.g.: reduced memory, risk of falls). E21 - Guidance on home care for someone in the family of the patient, as: dressings, exchange of tubes/ probes, bed bath. E22 - Inclusion in the supplementary feeding program (e.g.: milk and food). (Cronbach's alpha - 0.721, N=34).

\section{DISCUSSION}

The low percentage of doctors with specialization in the PC area was also found in other studies. This fact constituted a great challenge for PC qualification, since, without enabled professionals, changes in the care paradigm will rarely happen. It is inferred that low qualifications are related to professional turnover. The high turnover of professionals is associated with precarious work bonds, absence of appropriate qualifications, commute time and lack of materials for the accomplishment of tasks.

When comparing the evaluations of professionals with specialization with the ones without specialization, significant differences are met for the second group, which evaluated better the attributes first contact access, coordination - integration of care and essential score. This result opposes the literature that present the most qualified professionals to evaluate PC better .

On the attribute first contact access - accessibility, the low evaluations for the items about the working schedule and the communication with the unit and its professionals demonstrate reality, therefore, in the micro region of Alfenas, the units of FHS work in a commercial schedule on working days during the week and many health units had no telephone. Such fact reflects the non-availability of the team for caring for the client on schedules such as night shifts and weekends, mainly related to acute events, as shown in other evaluations. In order for the FHS to provide accessibility for first contact, schedules of the health units must be extended and technologies such as telephone and email, among others, must be used to extend means of communication.

In the evaluation from professionals, the attribute Coordination - Integration of Care received a high average score. This result speaks in favor of the efforts for the consolidation of health services in the regional guided format, initiated in 2003, by the implementation of the Managing Plan of Region-guided format Since then, the Plan has been organizing investments, contracts and agreement; aiming at implementing and keeping services that cover care gaps with care planning and scales; 
and providing for the health needs of the population in the small cities of the region. Moreover, the negative evaluation of the item concerning counter-referral to higher complexity services in PC stands out.

The bad quality of counter-referral to PC also was a question raised in other research, in which the professional participants report never or almost never receiving information about the services provided at the secondary level, or in about half of the appointments. Some cities in the State of the Paraná have solved this problem through implementation of an integrated electronic medical file system that enables accessing results of examinations and clinical reports created by other care levels. Such informational apparatus is not available in the region of the present study.

Also, it is important to point out that the FHS has the purpose of functioning as an entrance door and as filter of the flow within the health system. The PC professional must play the role of the coordinator of care to the clients, leading them through the care network in the search for the best possible care quality. For this, establishing and strengthening the flow of information within the services network is needed. Moreover, this coordination is essential for the attainment of other aspects. Without it, the longitudinal reach loses much of its potential, comprehensiveness is difficult and the function of the first contact .

Negative evaluations of the attribute Comprehensiveness - Available Services suggest that health professionals are not developing their action based on analysis of the health situation and the local reality. They are restricted to fulfilling what is determined by the governmental programs, not comprehensively.

Amongst the other items with negative evaluations, the one regarding the treatment of licit and illicit drugs use stands out in PC. The demand for treatment for drug users is not an exclusive responsibility of the healthcare system. Actions of the Comprehensive Care Policies for Alcohol and Drug Users foresees the participation of other public areas, such as education, security, social work and justice. But this policy has in the FHS teams one of the main performers of health care, in the aspects of health promotion and protection and prevention of complications, due to its organizational form and the proximity to the population. Studies show that, in the opinion of

\section{REFERENCES}

1. Levcovitz E, Lima LD, Machado CV. Política de saúde nos anos 90: relações intergovernamentais e o papel das Normas Operacionais Básicas. Ciên Saúde Coletiva [Internet]. 2001 [citado 2013 nov. 25];6(2):269-91. Disponível em: http:// www.scielo.br/pdf/csc/v6n2/7003.pdf health professionals, care service for drug users is not incorporated in the FHS and, when existing, it is centered on the treatment of acute intoxication symptoms.

\section{CONCLUSION}

Health professionals in the micro region of Alfenas provide, in general, good evaluations of the attributes of primary care considered in this study. Results suggest that the majority of attributes was incorporated in professional practice. Despite this information, the attributes First Contact Access - Accessibility, Coordination - Integration of Care and Comprehensiveness - Available Services still present problems to be solved. Difficulties to overcome these problems include precarious qualifications of a majority of medical professionals and in the interference of organizational arrangements, at the municipal and micro regional levels.

The combination of restricted schedules and the archaic forms of communication, with little use of communication technologies such as the Internet and the telephone, do not favor the access of the client to healthcare services. Also, regarding integration and coordination of the care, the region needs mechanisms that will ensure counter-referral of secondary and tertiary services to the guarantee of quality of the PC. If clients can access the FHS but cannot obtain continuation of services for the therapeutic project at higher complexity levels, the ability to solve health problems is compromised and discredited, breaking the caretaker-client bond. The FHS, and also PC, are neither able to provide for the health needs of the population described here, nor constitute a point of favorable convergence for the inter-sectorial format of public policies that interfere in social determinant grievances and are not specific illnesses.

The importance of this study, beyond the considerations presented, lies in the choice of small- and mediumsized cities for evaluation of the FHS. Cities with these characteristics are supported by the regional format; however, they still have difficulties holding professionals and offering clients a network of health services, with various complexity levels, in which the FHS occupies the central point. These questions became evident in the evaluation of the considered attributes and must be taken into consideration as the possibilities and limits of a decentralized, municipal and regional health system are discussed.

2. Ermel RC, Fracolli LA. O trabalho das enfermeiras no Programa de Saúde da Família em Marília/SP. Rev Esc Enferm USP [Internet]. 2006 [citado 2013 set. 19];40(4):533-9. Disponível em: http://www.scielo.br/pdf/reeusp/v40n4/v40n4a11.pdf 
3. Starfield B. Atenção primária: equilíbrio entre necessidades de saúde, serviços e tecnologia. Brasília: Unesco; 2002.

4. Brasil, Ministério da Saúde. Portaria n. 648, de 28 de março de 2006. Aprova a Política Nacional da Atenção Básica, estabelecendo a revisão de diretrizes e normas para a organização da Atenção Básica para o Programa Saúde da Família (PSF) e o Programa Agentes Comunitários de Saúde (PACS). Diário Oficial da União, Brasília, 29 mar. 2006. Seção 1, p.71.

5. Brasil. Ministério da Saúde; Secretaria de Atenção em Saúde, Departamento de Atenção Básica. PNAB - Política Nacional de Atenção Básica [Internet] Brasília; 2012 [citado 2013 nov. 26]. Disponível em: http://189.28.128.100/dab/docs/publicacoes/ geral/pnab.pdf

6. Donabedian A. Evaluating the quality of medical care, 1966. Milbank Q [Internet]. 2005 [cited 2013 Nov 26];83(4):691729. Available from: http://www.ncbi.nlm.nih.gov/pmc/ articles/PMC2690293/

7. Harzheim E, Starfield B, Rajmil L, Álvarez-Dardet C, Stein AT. Consistência interna e confiabilidade da versão em português do instrumento de avaliação da atenção primária (PCATool-Brasil) para serviços de saúde infantil. Cad Saúde Pública. [Internet]. 2006 [citado 2013 nov. 26];22(8):1649-59. Disponível em: http://www.scielo.br/pdf/csp/v22n8/13.pdf

8. Harzheim E, Oliveira MMC, Agostinho MR, Hauser L, Stein AT, Goncalves MR, et al. Validação do Instrumento de Avaliação da Atenção Primária à Saúde: PCATool-Brasil adultos. Rev Bras Med Fam Comunidade [Internet]. 2013 [citado 2014 jan. 17];8(29):274-84. Disponível em: http://www.rbmfc.org.br/ rbmfc/article/view/829/588

9. Hauser L, Castro RCL, Vigo A, Trindade TG, Gonçalves MR, Stein AT, et al. Tradução, adaptação, validade e medidas de fidedignidade do Instrumento de Avaliação da Atenção Primária à Saúde (PCATool) no Brasil: versão profissionais de saúde. Re Bras Med Fam Comunidade [Internet]. 2013 [citado 2014 jan. 17];8(29):244-55. Disponível em: http://www. rbmfc.org.br/rbmfc/article/view/821

10. Novaes HMD. Avaliação de programas, serviços e tecnologias em saúde. Rev Saúde Pública [Internet]. 2000 [citado 2013 nov. 27];34(5):547-9. Disponível em: http://www.scielo.br/ $\mathrm{pdf} / \mathrm{rsp} / \mathrm{v} 34 \mathrm{n5} / 3227 . \mathrm{pdf}$

11. Polit D, Beck C, Hungler B. Fundamentos de pesquisa em enfermagem. 5a ed. Porto Alegre: Artmed; 2004.

12. Brasil. Ministério da Saúde; Secretaria de Atenção em Saúde, Departamento de Atenção Básica. Manual do Instrumento de Avaliação da Atenção Primária à Saúde: Primary Care Assessment Tool PCATool - Brasil. Brasília; 2010.
13. Castro RCL, Knauth DR, Harzheim E, Hauser L, Duncan BB. Avaliação da qualidade da atenção primária pelos profissionais de saúde: comparação entre diferentes tipos de serviços. Cad Saúde Pública [Internet]. 2012 [citado 2013 dez. 2];28(9):1772-84.

14. Kolling JHG. Orientação à atenção primária à saúde das equipes de saúde da família nos municípios do projeto Telessaúde RS: estudo de linha de base [dissertação]. Porto Alegre: Faculdade de Medicina, Universidade Federal do Rio Grande do Sul; 2008.

15. Leão CDA, Caldeira AP. Avaliação da associação entre qualificação de médicos e enfermeiros em atenção primária em saúde e qualidade da atenção. Ciên Saúde Coletiva [Internet]. 2011 [citado 2013 set. 19];16(11):4415-23. Disponível em: http://www.scielosp.org/pdf/csc/v16n11/ a14v16n11.pdf

16. Gil CRR. Formação de recursos humanos em saúde da família: paradoxos e perspectivas. Cad Saúde Pública. 2005;21(2):490-8.

17. Campos CVA, Malik AM. Satisfação no trabalho e rotatividade dos médicos do Programa de Saúde da Família. Rev Adm Pública [Internet]. 2008 [citado 2013 set. 20];42(2):347-68. Disponível em: http://www. scielo.br/pdf/rap/v42n2/07.pdf

18. Chomatas E, Vigo A, Marty I, Hauser L, Harzheim E. Avaliação da presença e extensão dos atributos da atenção primária em Curitiba. Rev Bras Med Fam Comunidade [Internet]. 2013 [citado 2013 dez. 10];8(29):294-303. Disponível em: http://rbmfc.org. $\mathrm{br} /$ index.php/rbmfc/article/view/828

19. Giovanella L, Escorel S, Mendonça MHM. Porta de entrada pela atenção básica? Integração do PSF à rede de serviços de saúde. Saúde Debate. 2003;27(65):278-89.

20. Almeida PF, Fausto MCR, Giovanella L. Fortalecimento da atenção primária à saúde: estratégia para potencializar a coordenação dos cuidados. Rev Panam Salud Publica [Internet]. 2011 [citado 2013 set. 20];29(2):84-95. Disponível em: http://www.scielosp. org/pdf/rpsp/v29n2/a03v29n2.pdf

21. Malachias I, Leles FAG, Andrade LCF, Alencar FB, Pinto MAS, Silva AE, et al. O PDR - Plano Diretor de Regionalização da Saúde de Minas Gerais. Belo Horizonte: Secretaria do Estado da Saúde; 2010.

22. Serra CG, Rodrigues PHA. Avaliação da referência e contrarreferência no Programa Saúde da Família na região metropolitana do Rio de Janeiro (RJ, Brasil). Ciên Saúde Coletiva [Internet]. 2010 [citado 2014 jan. 20];15(6):3579-86. 
23. Cunha CRH. Percepção da qualidade da atenção à saúde infantil pelos médicos e enfermeiros: comparação entre o Programa Saúde da Família e o modelo tradicional [dissertação]. Porto Alegre: Faculdade de Medicina, Universidade Federal do Rio Grande do Sul; 2006.

24. Macinko J, Almeida C, Oliveira E. Avaliação das características organizacionais dos serviços de atenção básica em Petrópolis: teste de uma metodologia. Saúde Debate. 2003;27(65):243-56.

25. Figueiredo AM, Kuchenbecker RS, Harzheim E, Vigo Á, Hauser L, Chomatas ERV. Análise de concordância entre instrumentos de avaliação da atenção primária à saúde na cidade de Curitiba, Paraná, em 2008. Epidemiol Serv Saúde [Internet]. 2013 Mar [citado 2013 nov. 27];22(1):41-8.
26. Vitoria AM, Harzheim E, Takeda SP, Hauser L. Avaliação dos atributos da atenção primária à saúde em Chapecó, Brasil. Rev Bras Med Fam Comunidade. 2013;8(29):285-93.

27. Brasil. Ministério da Saúde; Secretaria Executiva, Coordenação Nacional de DST e AIDS. A Política do Ministério da Saúde para a Atenção Integral a Usuários de Álcool e outras Drogas. Brasília; 2003.

28. Santos JAT, Oliveira MLF. Implantação de ações para enfrentamento do consumo de drogas na atenção primária à saúde. Cogitare Enferm [Internet]. 2013;18(1):21-8. Disponível em: http://ojs.c3sl.ufpr. br/ojs/index.php/cogitare/article/view/28977/20009

29. Vargas D, Oliveira MAF, Luís MAV. Atendimento ao alcoolista em serviços de atenção primária à saúde: percepções e condutas do enfermeiro. Acta Paul Enferm. 2010;23(1):73-9.

Financed by the National Council for Scientific and Technological Development (CNPq), process no. 473768/2011-9. 